\title{
Microflora Associated with Smoked Shrimps Sold in different Markets
}

\author{
J. Daramola, C. Kester and A. Adeleye
}

\begin{abstract}
This research was aimed at assessing the microorganisms associated with smoked shrimps retailed in three market locations in Ota Metroplolis, Ogun State. The samples were collected from Iyana-iyesi, Oju-Ore and Sango markets of the town. Six samples of shrimp were purchased from two different retailers at each market per trial or visit. Microbial risk assessment of these smoked shrimps (ready-to-eat) was carried out in the Bells University Microbiology laboratory and the analyses was done using MacConkey agar (MCA), Nutrient agar (NA), Mannitol salt agar (MSA) and Eosin methylene blue agar (EMB) to isolate bacteria, while Potato dextrose agar (PDA) was used to isolate fungi. The total bacterial counts for all the samples ranged from $1.5 \times 101 \mathrm{CFU} / \mathrm{g}$ to $1.76 \times 102 \mathrm{CFU} / \mathrm{g}$. The microorganisms isolated and identified in the various markets implied that the bacteria genera: Staphylococcus aureus and Citrobacter species dominated the samples while the fungi genera that occurred most frequently in the samples were Aspergillus niger. The isolated bacteria have been implicated in various health risks such as food poisoning, food spoilage and medical complications. The health implication to consumers and the public health significance was also highlighted.
\end{abstract}

Keywords - micro-organisms, smoked shrimp, markets, health.

J. Daramola- Bells University of Technology, Ota, Ogun State. Nigeria

C. Kester- Bells University of Technology, Ota, Ogun State. Nigeria

A. Adeleye- Bells University of Technology, Ota, Ogun State. Nigeria.

\section{INTRODUCTION}

$\mathrm{S}$ eafood refers to all fresh or salt water organisms such as shellfishes e.g. shrimp, fin fishes, mollusks, crustaceans and all other forms of aquatic animal life. Shrimp continues to represent one of the safest forms of muscle protein consumed in the world. Seafood products are generally safe for consumption although, the bacterial load is high especially at the time of harvest due to the harvest techniques adopted. Poor post-harvest handling which may have removed the slime or protective covering on these aquatic species, poor processing techniques of such products also lead to an increase in the microbial load on these products. It is an extremely perishable commodity and quality loss can occur very rapidly after catch [5].

Since fish are composed of perishable nutrients, storage

J. Daramola, C. Kester and A. Adeleye are as working Senior Lecturer, Bells University of Technology, Ota, Ogun State, Nigeria period should be kept to a minimum with adequate storage conditions provided so as to prevent deteriorative changes occurring through oxidative damage and/or microbial, insect or rodent infestation. The most important environmental factors governing the storage or shelf life of fish are ambient temperature and humidity. These factors dictate the rate at which chemical changes take place [4]. In order to ensure that shrimp remains in good condition and is contaminant free, proper handling between capture and delivery to the consumer is a crucial element in ensuring quality of the final product. Standard of sanitation, handling method, time and holding temperature also affect shrimp quality.

In Nigeria, shrimp is harvested from unknown tropical waters and studies by previous research reported high level of bacterial contamination with Pseudomonas sp. as the main spoilage bacteria [2]. Past researches have shown that Staphylococcus aureus and Citrobacter spp were found in samples of smoked shrimp while the fungal specie that occurred most frequently in the samples was Aspergillus niger [11]. These organisms are a major cause of health problems; also they accelerate the deterioration process of the shrimp and shorten the shelf life of the shrimp.

Amongst seafood, shrimp is possibly the least problematic product in terms of reported illnesses per volume consumed [14]. The Food and Agricultural Organization of United Nation and the World Health Organization; Codex Alimentarius Commission [8] stated that illness due to contaminated food is perhaps the most widespread health problem in the contemporary world and an important cause of reduced economic productivity. Meanwhile, in order to prevent spoilage and increase shelf life of fresh shrimp, value adding through further processing (e.g. smoking) is necessary. Unfortunately, much of the shrimp smoked today is exposed to smoke just long enough to provide the desired flavour with little if any drying (Chinivasagama et al., 1996; Piggot, 2009. In: Olaoye et. al. 2014) [3; 15 In: 13], making the prawns susceptible to spoilage.

In the present research, an attempt was made to investigate the micro-organisms associated with smoked shrimp in selected market locations in Ota, Ogun state. Therefore, the general objective of this work is to carry out microfloral analyses on smoked shrimp retailed in some selected in some selected markets in Ota metropolis, Ogun state, Nigeria. 


\section{MATERIALS AND METHODS}

A preliminary survey was carried out to identify the retailing locations of smoked shrimp in the selected markets.

\section{A. Study Area}

Ready-to-eat smoked dried shrimp were bought from retailers at different markets in Ota. The samples were from three different markets; Iyana (A), Oju-Ore (B), Sango(C). A total number of 6 samples were collected (2 from each location) and the samples included the carapace and the exoskeleton of the shrimp. The samples were collected on Fridays of each week for 3 weeks. The shrimp procured were taken to the Microbiology Laboratory of Bells University of Technology for analysis and these samples were labeled: A1, A2, B1, B2, C1, C2.

$\mathrm{A} 1=$ Retailer 1 in Iyana; $\mathrm{A} 2=$ Retailer 2 in Iyana; $\mathrm{B} 1=$ Retailer 1 in Oju-Ore, B2 = Retailer 2 in Oju-Ore; $\mathrm{C} 1=$ Retailer 1 in Sango; C2 = Retailer 2 in Sango, -2 = diluent 2 ; $3=$ diluent 3 .

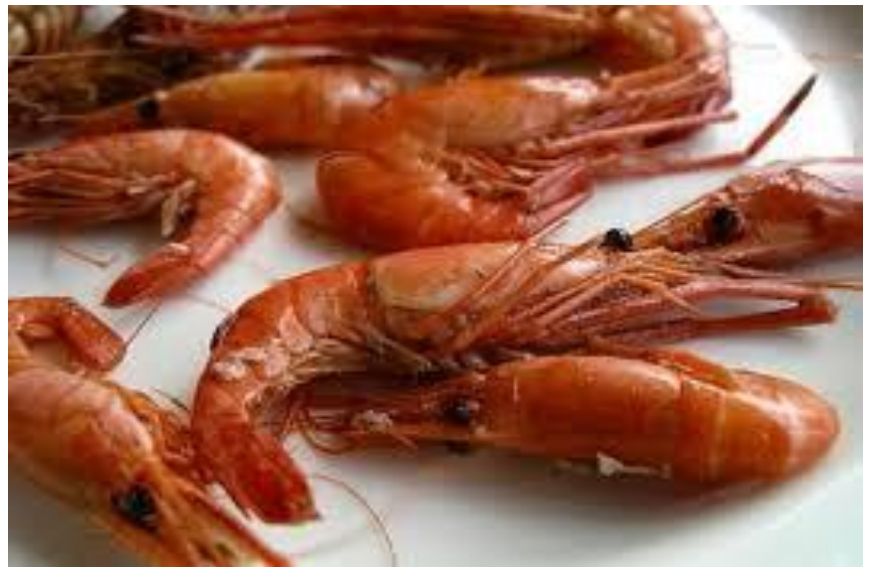

Fig. 1 : Samples of smoked shrimp purchased from selected markets

\section{B. Sample preparation and Analytical Procedures}

Using a sterile warring blender samples were blended into powder form and kept in sampling bottles.

The analytical procedures included: diluents and media preparation, serial dilutions, sterilization, isolation, identification and purification of isolates and Gram staining.

Other Biochemical tests carried out were Catalase Test, Citrate Utilisation Test [9], Oxidase Test; Sulphide Indole Motility Test and Kligler Iron Agar Test.

\section{RESULTS AND DISCUSSION}

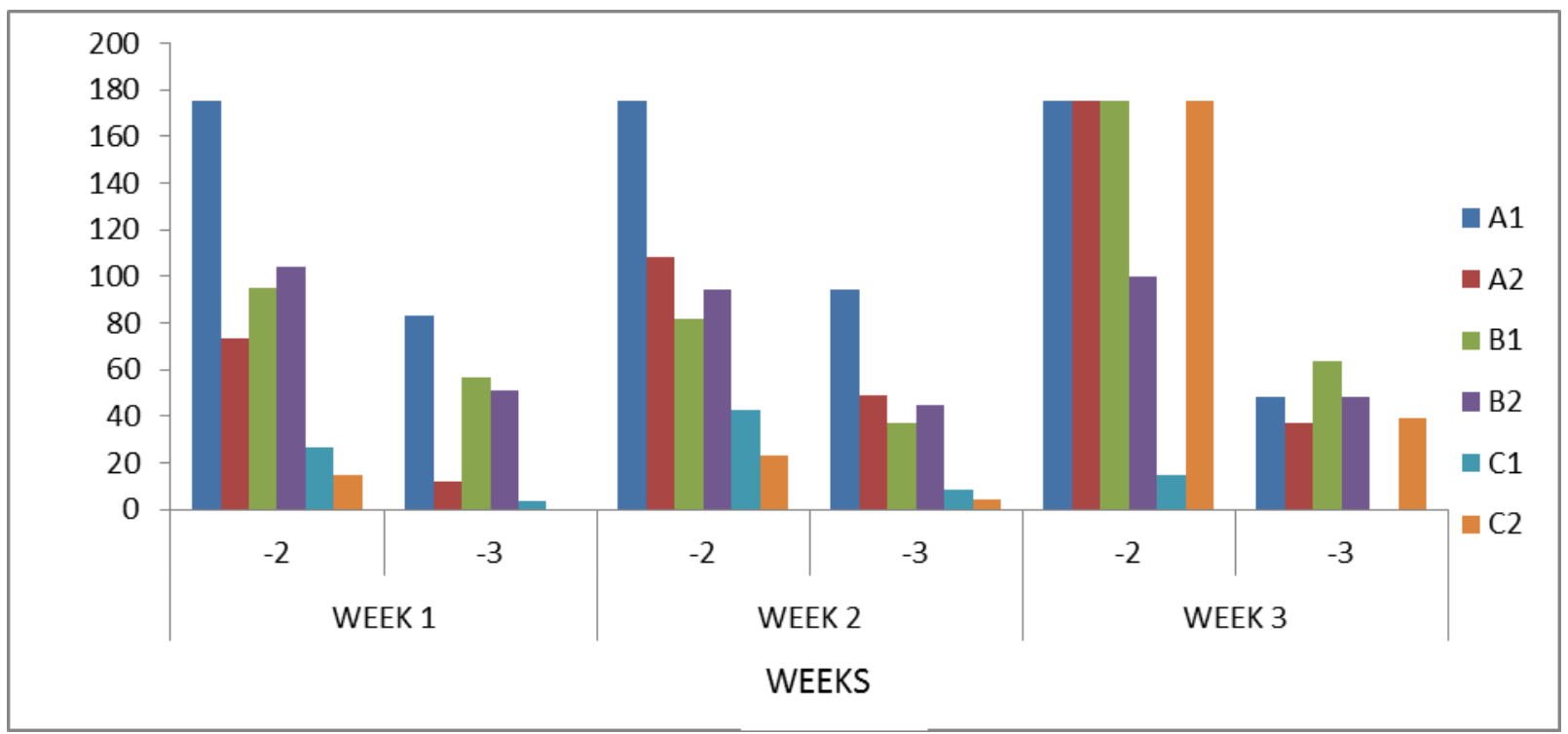

Fig. 2: Comparison of Total plate counts of smoked shrimp samples from six retailers for 3 weeks 


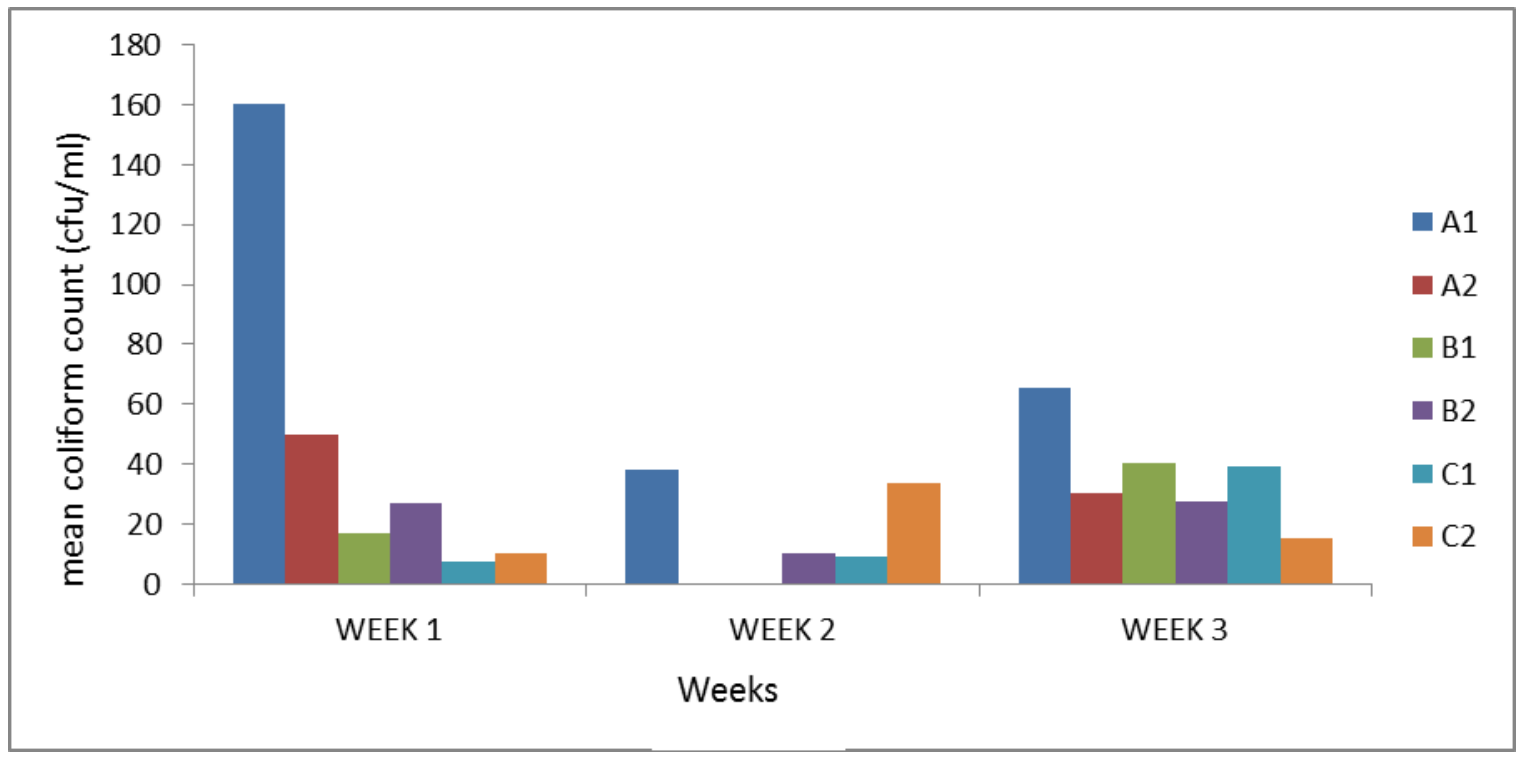

Fig. 3: Comparison of total coliform counts of smoked shrimp sample from six retailers for 3 weeks

TABLE I: IDENTIFICATION OF BACTERIAL ISOLATES FROM SAMPLES

\begin{tabular}{|c|c|c|c|c|c|c|c|c|c|c|c|c|c|}
\hline SAMPLE & $\mathrm{CC}$ & GR & $\mathrm{K}$ & A & $\mathrm{H}_{2} \mathrm{~S}$ & $\mathrm{G}$ & OXI & CIT & CAT & $\mathrm{S}$ & MOT & IND & Suspected organisms \\
\hline 1 & Cocci & + & + & - & + & - & - & + & + & + & - & - & Staphylococcus aureus \\
\hline 2 & Rod & - & + & - & - & + & + & + & + & - & + & - & Pseudomonas aeruginosa \\
\hline 3 & Rod & - & + & + & - & - & - & - & + & - & - & - & Shigella spp \\
\hline 4 & & - & - & + & - & & - & + & + & & + & - & Citrobacter spp \\
\hline 5 & Rod & - & - & + & - & & - & + & - & - & - & - & Klebsiella spp \\
\hline 6 & Rod & + & - & - & - & & & + & + & & - & - & Bacillus spp \\
\hline 7 & Rod & - & + & + & + & & - & + & + & + & + & - & Proteus spp \\
\hline 8 & & - & + & - & - & + & - & - & - & - & + & - & Serratia spp \\
\hline 9 & Cocci & + & - & + & - & - & - & - & - & - & - & - & Enterococcus feacalis \\
\hline
\end{tabular}

Morphological descriptions of the isolated fungi from the shrimp samples

\section{DISCUSSION}

Across the three weeks samples from retailer 1 in Iyanaiyesi market had the highest bacterial count and samples gotten from the Sango retailers had the least contaminants. This might be because retailer 1 in Iyana has an open stall beside a gutter and the Iyana environment is an untarred road generally dusty during the dry season and flooded during the raining season so there is always a high risk of contamination while the Sango retailers are situated on a tarred road that is clean and the retailers are in a closed environment.

Bacteria from different genera was isolated and identified from the prawn samples gotten from the 3 market locations in Ota. Bacteria family: Staphylococcus aureus and Citrobacter spp dominated the samples while Bacillus cereus, other bacteria species occurred sparingly. The fungi class: Aspergillus niger dominated the samples. Only one class of yeast and mould (Candida $\mathrm{sp}$ ) was isolated and identified from the samples. The presence of microorganisms in these samples might be the result of contamination during sales or unhygienic handling of the prawns by the sellers who display the products in the market place without covering them. In a similar study conducted by [6], on the significance of fungi associated with smoked-cured Ethmalosa fimbriata and Clarias gariepinus, it was observed that the nutrient value of these smoked-cured fish is not significantly diminished by the smoking process but that the economic value may be determined by the quality of the fish presented for sale. It was also observed in this study that the presence of fungi particularly aflatoxigenic moulds in these fish species is very significant from a food safety point. 
The presence of micro- organisms in these samples might be the result of contamination during sales or unhygienic handling of the shrimp by the sellers who display the products in the open market places without covering them [7]. This is in agreement with the findings of [10] who reported the lack of hygiene and sanitary practices by workers during handing of shrimp in which the pathogenic organisms are present and sometimes added to the product. Meanwhile, this might have adverse effect on the health of the consumers [1; 12].

A study was also carried out by [11] to identify the microorganisms present in prawn species gotten from Abeokuta, Ogun state. Most of these organisms found on the seafood products are those commonly found in soil and water. Furthermore, it was observed that locally smoked prawns harboured microorganisms which are either of pathogenic, food poisoning, food spoilage or of epidemiological importance, hence; this study provides the knowledge on the microorganisms associated with smoked shrimp purchased from 3 different market locations in Ota. It was however observed from the results that consumers which consume these smoked prawns without further cooking, washing or heating are at a risk of contracting food borne infections as a result of poor hygiene and poor postharvest handling on the part of the sellers.

\section{V.CONCLUSION}

In conclusion, Shrimp which serves as an alternative source of animal protein cannot be banned from consumption based on its nutritional values; hence efforts should be made by relevant organizations on the formulation and enforcement of laws which would promote proper post-harvest technologies and good hygiene practice of shrimp and other seafood products. Also, efforts should be geared towards awareness programs amongst food vendors about safe and hygienic practices and its importance to the health of man. Consumers also need to recognize that a healthy food means a healthy body hence, shrimp and other foods purchased from open markets should be processed further through washing and heating.

\section{RECOMMENDATIONS}

a. Smoked shrimp packaging should be fly-proof in order to prevent the invasion of microbial growth on the products.

b. Proper handling, processing and preservation of the shrimp and other sea foods must be hygienically done.

c. Consumers of smoked shrimp and other sea foods should wash and subject these products to further cooking or heating so as to deactivate all heat labile microorganisms present.

\section{REFERENCES}

[1] Adebolu, T. T. and Ifesan, B. O. (2001). Bacteriological quality of vegetables used in salads. Nigerian Journal of Microbiology. 15(1): 8185.

[2] Aribisala, O. A. (1975). The quantitative and qualitative bacteriology of shrimp and the role of bacteria in shrimp spoilage. Annual report. Ministry of Agriculture and Rural Development Discussion, Nigeria.
[3] Chinivasagama, H. N., Bermner, H. A.,Thrower, S. J., Nottingham, S. M. (1996). Spoilage pattern of 5 species of Australian Prawn; Journal of Af. Food Prod tech, 5(1): 25 -50.

[4] Daramola, J. A., Fasakin, E. A.,Adeparusi, E. O. (2007). Changes in Physicochemical and Sensory Characteristics of Smoke-Dried Fish Species Stored at Ambient Temperature. African Journal of Food Agriculture Nutrition and Development, 7: 6 https://doi.org/10.18697/ajfand.17.1980

[5] Dewi, R. S., Nurul Huda, G. and Ahmad, R. (2011). Changes in the physiological properties, microstructure and sensory characteristics of shark dendeng using different drying methods. American Journal of Food Technology 6:149-157. https://doi.org/10.3923/ajft.2011.149.157

[6] Edema M. O. and Agbon A. O. (2010). Significance of fungi associated with smoke cured Ethmalosa fimbriata and Clarias gariepinus. Journal of food processing and preservation. V.34 pp. 355-363. https://doi.org/10.1111/j.1745-4549.2009.00426.x

[7] Ehigiator, F. A. R., Akise, O. G. and Eyong, M. M. (2014). Bacteria and Fungi Load of Raw Processed Shrimp from different Meat Shops in Benin Metropolis. Nigerian Journal of Agriculture, Food and Environment. 10(3): 1- 7

[8] FAO/WHO Codex Alimentarius Commission (2000). Recommended Code of Practice Shrimps/ prawns (CAC/RCP17 -1978; Quick Frozen shrimps/ prawns (Revised 1 - 1995).

[9] Fawole, M. O., and Oso, B. A. (2001). Laboratory manual in Microbiology. 1st edition, Spectrum books Ltd. Ibadan, Nigeria, ISBN: 978- 246-032-X

[10] ObhidulHuq, A. K., Shabudden. A., Shifat, M. D., and Arefin, A. (2010). The effect of HACCP based personal Hygiene on the products of Galda Prawn (Macrobrachium rosenbergii) at Processing zone in Khulna, Bangladesh. Food and Public Health Journal 2, (6):254-258.

[11] Oduneye, O. A. (2010). The microorganisms associated with smoked prawns in Abeokuta Metropolis, Ogun State, Nigeria. A project report submitted to the Department of Aquaculture and Fisheries Management.

[12] Okonko, I. O., Ogunjobi, A. A., Fajobi, E. A., Onoja, B. A., Babalola, E. T. and Adedeji, A. O. (2008). Comparative studies and microbial rist assessment of different ready - to - eat (RTE) frozen sea foods processed din Ijora-Olopa, Lagos state, Nigeria. Africa Journal Biotechnology 7(16): 2898- 2901.

[13] Olaoye, O. J., Akinyemi, A. A., Oduneye, O. A. and G. N. O. Ezeri (2014). Micro- Organisms Associated with Smoked Prawn (Macrobranchium Spp.) in Selected Market Locations in Abeokuta Metropolis of Ogun State, Nigeria. Journal of Agricultural Science and Environment. 14:109-117

[14] Otwell, W. S., George, J. F. (2010). A HACCP Program for Raw, Cultured Penaeid

Shrimp. Florida Sea Grant College Program. E/TP-1 P. 218

[15] Pigott, G. M. (2009). Flavours and acceptance of formulated seafood products Food Reviews. International Seafood's: Quality and Evaluation 